\title{
EFFECT OF POWDERY MILDEW ON MANGO CHLOROPHYLL CONTENT AND DISEASE CONTROL
}

\author{
ABO REHAB, M. E. A., NADIA A. SHENOUDY AND H.M.ANWAR
}

Plant Pathol. Res. Inst., ARC, Giza, Egypt

(Manuscript received 3 March 2013)

\begin{abstract}
Powdery mildew caused by Oidium mangiferae is a serious disease of Mango. Survey of the disease was conducted during seasons 2011 and 2012 in Sharkeya, Behera, Ismailía and Giza as well as Noubareya district. The highest disease severity (\%) was observed in Ismailía being (46.6\%) and the lowest in Giza (23.6\%). Five different fungicides namely Punch, Bayleton, Kema-Z, Colis, Billis and one biocide ( AQ 10) were used as spraying treatments to control the disease on four Mango cultivars (Langara, Zebda, Alphonso and Fagri Kelan) grown at Noubareya district. Punch gave the highest efficiency in controlling the disease being (78.9 and $79.4 \%$ in 2011 and 2012, respectively) whereas AQ 10 gave the lowest efficiency (57.0 \% and 55.3\%). Using the fungicides tested and the biocide maintained the chlorophyll content at comparative level with the healthy tissue. The untreated infected control showed reduced in chlorophyll content. The yield increased by using fungicides and biocides ranging from $307.4 \%$ to $35.5 \%$ depending on the treatment and cultivar. The increase in income occurred as a result of reducing disease severity which led to maintaining chlorophyll content and photosynthesis.
\end{abstract}

\section{INTRODUCTION}

Mango (Mangifera indica L.) is universally one of the most popular edible fruit crops. In Egypt, the areas cultivated reached 222838 feddans (169068 feddan as fruiting trees) with an approximate production of 598084 metric tons (Anonymous, 2011). Powdery mildew is one of the most serious diseases of mango affecting almost all the cultivars. Powdery mildew is caused by the fungus Oidium mangiferae, which may develop as sporadic infections causing severe crop loss before being epiphytotic leading to flower and panicle infection and subsequent failure of fruit set (Nofal et al, 2006 \& Haggag, 2010). Many researchers reported that chlorophyll content and leaf hair density were negatively correlated with susceptibility to powdery mildew. Furthermore, Infection on leaves results in destruction of chloroplast and in turn reduces photosynthesis, photophosphorylation and $\mathrm{CO}_{2}$ assimilation. The chlorophyll content of plants infected by powdery mildew was considerably lower than in healthy plants (Shukanov et al. 1980; Xu Bing Liang et al. 2005; Dinesh 2009).

The efficacy of many fungicides have been evaluated for disease control such as Bavistin (carbendazim), Sulfex (wettable sulfur), Bayleton (triademefon), Roko 
(thiophanate-methyl), Topas (penconazole), Contaf (hexaconazole), Rubigan (fenarimol), Punch (flusilazole), and Karathane (dinocap) (Chavan et al 2009; Sharma et al 2012). Also, Ampelomyces quisqualis (AQ10) as a biocontrol agent against powdery mildew was tested on different crop and trees, and it gave good results in reducing disease severity (Kiss et al ., 2004; Romero et al 2007)

The objective of this paper was to evaluate some treatments in controlling the disease and their effect on the chlorophyll content and yield.

\section{MATERIALS AND METHODS}

\section{Disease survey:}

Survey was conducted during spring seasons of 2011 and 2012 in Sharkeya, Behera, Ismailía, Giza governorates and Noubareya districts. Samples were chosen at random and examined. Results were recorded as disease severity according to Thind et al (2005) using a 0-5 scale, according to the following classes: $0=$ No symptoms; 1 $=1-20 \% ; 2=21-40 \% ; 3=41-60 \% ; 4=61-80 \%$ and $5=81-100 \%$ infected leaf area.

Percentage of disease severity was calculated according to following equation:

D.S. $\%=\Sigma(n \times c) / N$.C X100

Whereas: D.S. = Disease severity \%

$\mathrm{n}=$ Number of infected leaves per category

$\mathrm{c}=$ Category number

$\mathrm{N}=$ Total examined leaves

$\mathrm{C}=$ Maximum of category number of infection.

\section{Chlorophyll determination:}

The chlorophyll content was determined using portable chlorophyll meter (SPAD502, Minolta, Japan), as SPAD unit; these units were transformed to $\mathrm{mg} \mathrm{m}^{-2}$ as described by Monje and Bugbee (1992) as follows:

Chlorophyll content $\left(\mathrm{mg} \mathrm{m}^{-2}\right)=80.05+10.4($ SPAD 502).

Where: SPAD 502= chlorophyll meter reading $(C M R)$.

Percentage of reduction of chlorophyll content in infected leaves was calculated as following equation:

$\%$ reduction of chlorophyll content $=$ chlorophyll content in healthy leaves chlorophyll content in infected leaves / chlorophyll content in healthy leaves $\times 100$

\section{Chemical and biological control under field conditions:}

Mango cultivars Langara, Zebda, Alphonso and Fagri Kelan, grown at Noubareya districts, was sprayed with five different fungicides namely: Punch, Bayleton, Kema-Z, Colis, Billis and the biocides AQ 10 at the recommended doses 
(Table, 1). Three sprays; before flowering, during flowering and after fruit set were applied for two consecutive fruiting seasons (2011and 2012). Eight year-old Mango trees in Randomized Block Design were arranged for each treatment replicated three times (one tree per replication). Incidence and development of powdery mildew was recorded on four marked panicles and leaves in four sides of each mango tree. Disease severity was recorded using disease scale as previously mentioned.

Efficiency of fungicides in controlling the disease was calculated according to the following formula: $\%$ Efficiency $=$ Disease severity $\%$ in the control - Disease severity $\%$ in the treatment /Disease severity $\%$ in the control $\times 100$

Table 1. The fungicides and biocide tested.

\begin{tabular}{|l|l|c|}
\hline Trade name & Active ingredient & Dose/ 100 L water \\
\hline Punch 40\% EC & flusilazole and carbendazim & $6 \mathrm{ml}$ \\
\hline Bayleton 25\% EC & Triadimefo & $50 \mathrm{ml}$ \\
\hline Kema-Z 50\% WP & Carbendazim & $50 \mathrm{gm}$ \\
\hline Colis 30\% EC & Kresoxim-methyl and Boscalid & $50 \mathrm{ml}$ \\
\hline Billis 38\% WG & Boscalid and 12.8\% Pyraclostrobin & $30 \mathrm{gm}$ \\
\hline AQ 10 58\% WGD & Ampelomyces quisqualis & $3 \mathrm{gm}$ \\
\hline
\end{tabular}

\section{Economic study:}

Three trees of each cultivar were chosen randomly, average number of fruits/ tree was recorded in order to calculate the amount of fruit production in each treatment. Increase (\%) was calculated according to the following formula:

$\%$ increase of average number of fruits/ trees = average number of fruits in the treatment - average number of fruits in the control/ average number of fruits in the control $\times 100$. The value of the crop increase was estimated versus the cost of the applied treatment and the net balance was presented. However, Profit = crop price by Egyptian pound in the treatment - crop price by Egyptian pound in the control.

Statistical analyses : The data were statistically analyzed as complete randomized block design. Anova was performed on combined data for the two seasons and LSD was computed.

\section{RESULTS}

\section{Field survey}

Data in (Fig.1) showed that the highest percentages of disease severity and incídence of powdery mildew were reported during seasons 2011 in Ismailía (46.6 $\%$ and 61.5 ) followed by Noubareya, Sharkeya, Behera and Giza (39.3\% and $47.5 \%)$, (31.3\% and $37.0 \%),(28.2 \%$ and $29.6 \%)$ and (26.7 \% and 37.0$)$, respectively. Meanwhile, during season 2012 the highest percentage of disease severity and 
incídence observed in Ismailía (49.1\% and57.6\%) followed by Noubareya, Sharkeya, Behera and Giza (35.4\% and 51.6\%), (25.9\% and39.5\%), (25.3\%and 32.6\%) and (23.6\% and $42.5 \%)$, respectively.

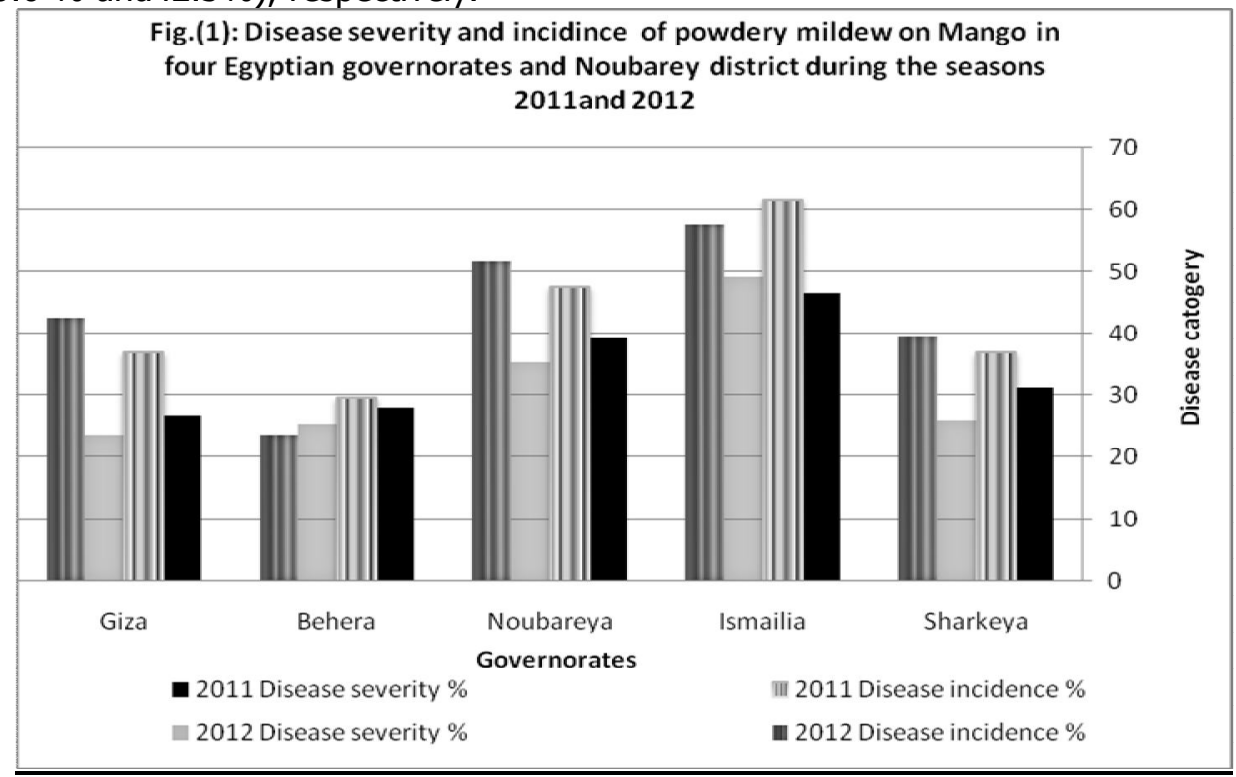

\section{Chlorophyll contents:}

Results presented in Table (2) indicate that there is an inverse relationship between the leaves content of the chlorophyll and the powdery mildew disease. Healthy leaves contain greater amount of chlorophyll than infected leaves in all varieties that have been studied. The rate of reduction in chlorophyll content of the infected leaves ranged between 25.6 and $38.3 \%$.

Table 2. Leaf content of chlorophyll ( $\left.\mathrm{mg} / \mathrm{m}^{-2}\right)$ of four Mango cultivars grown under natural infection of powdery mildew disease in Noubareya region conditions in 2011 and 2012 seasons.

\begin{tabular}{|l|c|c|c|c|c|c|}
\hline \multirow{2}{*}{ cultivars } & \multicolumn{6}{|c|}{ Chlorophyll $\left(\mathrm{mg} \mathrm{m}^{-2}\right)$} \\
\cline { 2 - 7 } & \multicolumn{7}{|c|}{2011} & \multicolumn{2}{c|}{2012} \\
\cline { 2 - 7 } & $\begin{array}{c}\text { Healthy } \\
\text { Leaf }\end{array}$ & $\begin{array}{c}\text { Infected } \\
\text { Leaf }\end{array}$ & $\begin{array}{c}\text { Reduction } \\
\%\end{array}$ & $\begin{array}{c}\text { Healthy } \\
\text { Leaf }\end{array}$ & $\begin{array}{c}\text { Infected } \\
\text { Leaf }\end{array}$ & $\begin{array}{c}\text { Reduction } \\
\%\end{array}$ \\
\hline Alphonso & 582.66 & 412.16 & 29.3 & 602.08 & 427.06 & 29.1 \\
\hline Fagri Kelan & 685.28 & 422.90 & 38.3 & 693.94 & 458.26 & 33.9 \\
\hline Langara & 595.84 & 396.56 & 33.4 & 619.06 & 438.16 & 29.22 \\
\hline Zebda & 666.90 & 496.40 & 25.6 & 698.69 & 499.36 & 28.5 \\
\hline
\end{tabular}

\section{Chemical and biological control under field conditions:}

Data in table (3) show that Punch gave the highest efficiency in reducing disease severity in Alphonso cultivar during season 2011and 2012 under natural infection (78.9 and 79.4\%), followed by Bellis, $(76.3,76.6)$ Collis, $(73.7,74.8)$ Bayleton, $(66.7,70.1)$ and Kema-Z $(65.7,66.4)$ respectively, whereas AQ 10 was the least effective $(55.3,56.7)$. Similar trend could be observed with Fagri Kelan cultivars. 
Table 3. Efficiency of five fungicides and one biocide against powdery mildew on two mango cultivars in Noubareya during the 2011and 2012 seasons.

\begin{tabular}{|c|c|c|c|c|c|c|c|c|}
\hline \multirow{3}{*}{ Fungicide } & \multicolumn{4}{|c|}{ cv. Alphonso } & \multicolumn{4}{|c|}{ cv. Fagri Kelan } \\
\hline & \multicolumn{2}{|c|}{2011 season } & \multicolumn{2}{|c|}{2012 season } & \multicolumn{2}{|c|}{2011 seasons } & \multicolumn{2}{|c|}{2012 season } \\
\hline & \% D.S & \% Eff. & $\%$ D.S & $\%$ Eff. & $\%$ D.S & $\%$ Eff. & $\%$ D.S & $\%$ Eff. \\
\hline Collis & 15.0 & 73.7 & 13.5 & 74.8 & 12.5 & 74.2 & 11.0 & 75.6 \\
\hline Bellis & 13.5 & 76.3 & 12.5 & 76.6 & 11.5 & 76.3 & 10.0 & 77.8 \\
\hline Punch & 12.0 & 78.9 & 11.0 & 79.4 & 9.5 & 80.4 & 8.5 & 81.1 \\
\hline Bayleton & 17.5 & 69.3 & 16.0 & 70.1 & 15.0 & 69.1 & 13.5 & 70.0 \\
\hline Kema-Z & 19.5 & 65.7 & 18.0 & 66.4 & 17.0 & 64.9 & 15.0 & 66.7 \\
\hline AQ 10 & 25.5 & 55.3 & 23.5 & 56.1 & 21.5 & 55.7 & 19.5 & 56.7 \\
\hline Control & 57.0 & & 53.5 & & 48.5 & & 45.0 & \\
\hline L.S.D 0.05 & & $\begin{array}{r}\text { Fungicide } \\
\text { Seasons } \\
\mathrm{F}^{*}\end{array}$ & N.S & & & $\begin{array}{r}\text { Fungicide } \\
\text { Season } \\
\mathrm{F}^{*}\end{array}$ & $\begin{array}{lr}\text { S): } & 1.9 \\
\text { S): } & 1 . \\
\text { N.S }\end{array}$ & \\
\hline
\end{tabular}

$\%$ D.S = \% Disease severity

$\%$ Eff. = \% Efficiency

Data presented in Table (4) show that Bellis gave the highest efficiency to reduce disease severity in field under natural infection during season 2011and 2012 on Langara cultivar being (84.7 and $87.3 \%$ ) followed by Punch, $(83.1,83.6)$ Collis, $(77.9,76.4)$ Bayleton. $(72.9,74.5)$, and Kema-Z $(67.8,69.1)$ but AQ 10 was lowest one $(57.6,58.2)$ On Zebda cultivar, Punch gave the highest efficiency to reduce disease severity in field under natural infection were ( 80.3 and $80.1 \%)$ followed by Bellis, $(78.9,79.4)$ Collis, $(76.3,76.5)$ Bayleton, $(71.1,70.6)$ and Kema-Z $(67.1,66.2)$ but AQ 10 was lowest one $(57.9,55.9)$.

Table 4. Evaluation of the efficiency of five fungicides and one biocide on powdery mildew severity (\%) on Langara and Zebda Mango cultivars in Noubareya during 2011/2012 seasons.

\begin{tabular}{|c|c|c|c|c|c|c|c|c|}
\hline \multirow{3}{*}{ Fungicides } & \multicolumn{4}{|c|}{ cv. Langara } & \multicolumn{4}{|c|}{ cv. Zebda } \\
\hline & \multicolumn{2}{|c|}{2011 season } & \multicolumn{2}{|c|}{2012 season } & \multicolumn{2}{|c|}{2011 season } & \multicolumn{2}{|c|}{2012 season } \\
\hline & $\%$ D.S & \% Eff. & \% D.S & \% Eff. & $\%$ D.S & \% Eff. & \% D.S & $\%$ Eff. \\
\hline Collis & 6.5 & 77.9 & 6.5 & 76.4 & 9.0 & 76.3 & 8.0 & 76.5 \\
\hline Bellis & 4.5 & 84.7 & 3.5 & 87.3 & 8.0 & 78.9 & 7.0 & 79.4 \\
\hline Punch & 5.0 & 83.1 & 4.5 & 83.6 & 7.5 & 80.3 & 6.5 & 80.1 \\
\hline Bayleton & 8.0 & 72.9 & 7.0 & 74.5 & 11.0 & 71.1 & 10.0 & 70.6 \\
\hline Kema-Z & 9.5 & 67.8 & 8.5 & 69.1 & 12.5 & 67.1 & 11.5 & 66.2 \\
\hline AQ 10 & 12.5 & 57.6 & 11.5 & 58.2 & 16.5 & 57.9 & 15 & 55.9 \\
\hline Control & 29.5 & & 27.5 & & 38.0 & & 34.0 & \\
\hline L.S.D 0.05 & & $\begin{array}{r}\text { Fungicide } \\
\text { Seasons } \\
F^{*}\end{array}$ & 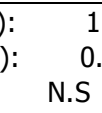 & & & $\begin{array}{r}\text { Fungicide } \\
\text { Season } \\
\mathrm{F}^{*}\end{array}$ & $\begin{array}{l}\text { ): } \\
\text { ): } \\
\quad \text { N.S }\end{array}$ & \\
\hline
\end{tabular}




\section{Effect of treatments on chlorophyll content.}

Using fungicides tested and biocide reduced the magnitude of decrease in chlorophyll content due to infection. Punch recorded the highest chlorophyll content compared to the control (Table 5). Chlorophyll was decreased from 585.84 to $396.56 \mathrm{mg} / \mathrm{m}^{2}$ in untreated control compared with using Punch in season 2011, and from 609.06 to $438.16 \mathrm{mg} / \mathrm{m}^{2}$ season 2012. Meanwhile, chlorophyll decreased from 542.5 to 396.56 $\mathrm{mg} / \mathrm{m}^{2}$ in untreated control compared with using Bellis in season 2011, and from 554.64 to $438.16 \mathrm{mg} / \mathrm{m}^{2}$ season 2012 on Langara variety. Whereas, on Zebda cultivar, chlorophyll content decreased from 656.90 to $5496.40 \mathrm{mg} / \mathrm{m}^{2}$ in untreated control compared with using Punch in season 2011, and from 668.69 to $469.36 \mathrm{mg} /$ $\mathrm{m}^{2}$ in 2012 , Also Chlorophyll content was decreased from 617.73 to $496.40 \mathrm{mg} / \mathrm{m}^{2}$ in untreated control compared with using Bellis in season 2011and from 640.96 to $469.36 \mathrm{mg} / \mathrm{m}^{2}$ season 2012.On the other hand, the biocide AQ10 gave the lowest stability in Chlorophyll content in both seasons.

Table 5. Effect of five fungicides and one biocide on leaf content of chlorophyll $\left(\mathrm{mg} \mathrm{m}^{-2}\right.$ ) Langara and Zebda cultivars grown under natural infection of powdery mildew disease in Noubareya region conditions in 2011 and 2012 seasons.

\begin{tabular}{|c|c|c|c|c|c|c|}
\hline \multirow{4}{*}{ Fungicide } & \multicolumn{6}{|c|}{ Chlorophyll $\left(\mathrm{mg} \mathrm{m}^{-2}\right)$} \\
\hline & \multicolumn{3}{|c|}{ cv. Langara } & \multicolumn{3}{|c|}{ cv. zebda } \\
\hline & \multicolumn{2}{|c|}{ Season } & \multirow{2}{*}{ Mean } & \multicolumn{2}{|c|}{ Season } & \multirow{2}{*}{ Mean } \\
\hline & 2011 & 2012 & & 2011 & 2012 & \\
\hline Collis & 529.33 & 534.53 & 531.93 & 594.50 & 605.60 & 600.05 \\
\hline Bellis & 542.50 & 554.64 & 548.57 & 617.73 & 640.96 & 629.34 \\
\hline Punch & 585.84 & 609.06 & 597.45 & 656.90 & 668.69 & 662.80 \\
\hline Bayleton & 514.77 & 524.48 & 519.62 & 584.80 & 588.26 & 586.53 \\
\hline Kema-Z & 495.36 & 507.49 & 501.42 & 563.30 & 579.94 & 571.62 \\
\hline AQ 10 & 468.66 & 476.98 & 472.82 & 521.01 & 546.32 & 533.66 \\
\hline Control & 396.56 & 438.16 & 417.36 & 496.40 & 469.36 & 482.88 \\
\hline Mean & 504.71 & 520.76 & & 576.38 & 585.45 & \\
\hline LSD at $(P<0.05)$ : & \multirow{2}{*}{\multicolumn{3}{|c|}{$=10.70$}} & \\
\hline Fungicides(F): & & & & $=4$ & & \\
\hline Seasons (S): & \multicolumn{3}{|c|}{$=5.72$} & \multicolumn{3}{|c|}{$=\mathrm{NS}$} \\
\hline $\mathrm{F} * \mathrm{~S}:$ & \multicolumn{3}{|c|}{$=15.13$} & \multicolumn{3}{|c|}{$=\mathrm{NS}$} \\
\hline
\end{tabular}

Results presented in Table (6) show that the control of powdery mildew led to a fixity in chlorophyll content in leaves during the two seasons of the study on Alphonso and Fagri klan cultivars compared to untreated control which decreased 
amount of chlorophyll, resulting from development of infection. Chlorophyll was decreased from 572.66 to $491.35 \mathrm{mg} \mathrm{m}^{2}$ in untreated control compared with using Punch in season 2011, and from 592.08 to $503.23 \mathrm{mg} \mathrm{m}^{2}$ season 2012 in Alphonso cultivar. Also, chlorophyll content in Fagri Klan cultivar during the 2011 season decreased from 675.28 to $567.17 \mathrm{mg} \mathrm{m}^{-2}$ and during the season of 2012 from 683.94 to $586.38 \mathrm{mg} \mathrm{m}^{-2}$. for the same mentioned fungicides.

In contrast, the least decreases were recorded with AQ10 in Alphonso cultivar during 2011 (from 454.1 to $412.16 \mathrm{mg} \mathrm{m}^{-2}$ ) and 2012 (from 465.39 to $427.0 \mathrm{mg} \mathrm{m}^{-2}$ ) in Fagri Klan cultivar during the 2011 season (from 510.16 to $422.9 \mathrm{mg} \mathrm{m}^{-2}$ ) and 2012 (from526.21 to $458.26 \mathrm{mg} \mathrm{m}^{-2}$ )

The highest decreases in chlorophyll content were recorded in untreated control compared with Punch application during 2011 season from 675.28 to 567.17 $\mathrm{mg} \mathrm{m}^{-2}$ in Fagri Klan cultivar.

Table 6. Effect of five fungicides and one biocide on chlorophyll content (mg/ $\mathrm{m}^{-2}$ ) in Alphonso and Fagri klan cultivars grown under natural infection of powdery mildew in Noubareya region in 2011 and 2012 seasons.

\begin{tabular}{|c|c|c|c|c|c|c|}
\hline \multirow{4}{*}{ Fungicide } & \multicolumn{6}{|c|}{ Chlorophyll $\left(\mathrm{mg} \mathrm{m}^{-2}\right)$} \\
\hline & \multicolumn{3}{|c|}{ CV. Alphonso } & \multicolumn{3}{|c|}{ cV. Fagri Kelan } \\
\hline & \multicolumn{2}{|c|}{ Season } & \multirow{2}{*}{ Mean } & \multicolumn{2}{|c|}{ Season } & \multirow{2}{*}{ Mean } \\
\hline & 2011 & 2012 & & 2011 & 2012 & \\
\hline Collis & 508.88 & 518.58 & 513.73 & 612.18 & 635.06 & 623.62 \\
\hline Bellis & 528.29 & 540.77 & 534.53 & 643.73 & 664.18 & 653.96 \\
\hline Punch & 572.66 & 592.08 & 582.37 & 675.28 & 683.94 & 679.61 \\
\hline Bayleton & 488.08 & 499.17 & 493.62 & 567.46 & 592.42 & 579.94 \\
\hline Kema-Z & 475.25 & 479.06 & 477.16 & 538.00 & 544.58 & 541.29 \\
\hline AQ 10 & 454.10 & 465.89 & 460.00 & 510.61 & 526.21 & 518.41 \\
\hline Control & 412.16 & 427.06 & 419.61 & 422.90 & 458.26 & 440.58 \\
\hline Mean & 491.35 & 503.23 & & 567.17 & 586.38 & \\
\hline $\begin{array}{l}\text { LSD at }(P<0.05) \text { : } \\
\text { Fungicides }(F) \text { : } \\
\text { Seasons }(S) \text { : } \\
F^{*} \text { : }\end{array}$ & \multicolumn{3}{|c|}{$\begin{array}{l}=16.28 \\
=8.7 \\
=\mathrm{NS}\end{array}$} & \multicolumn{3}{|c|}{$\begin{array}{l}=7.59 \\
=4.06 \\
=10.37\end{array}$} \\
\hline
\end{tabular}

\section{Economic study:}

Applying three spraying of five fungicides and one biocide against the disease increased average number of fruits/ tree compared to the untreated control on cv. Alphonso (Table, 7\&8). The highest percentage of increases during 2011 season in the average number of fruits/ tree were observed with Punch (307.4\%), Bellis (288.3\%) and Collis (244.4\%) and these fungicides increment the profit 332, 310 and 267 Egyptian pounds, respectively compared with the controls. Whereas, the least 
percentages were observed with AQ10 (156.6 \% \& $119.7 \%)$. and the profits were (164 \&211) Egyptian pounds during 2011and 2012 season. As for Fagri Kelan, similar positive results in increased average number of fruits/ tree and profits were observed.

Table 7. Effect of five fungicides and one biocide on fruit yields in Alphonso mango cultivars in Noubareya districts, 2011 and 2012 seasons.

\begin{tabular}{|c|c|c|c|c|c|c|c|c|c|c|}
\hline \multirow{2}{*}{ Fungicides } & \multicolumn{5}{|c|}{ 2011season } & \multicolumn{5}{|c|}{2012 season } \\
\hline & YK* & $Y^{*}$ & $I^{*}$ & $P$ & Profit & YK* & $\mathrm{Y}^{*}$ & I* & $P$ & Profit \\
\hline Collis & 37.5 & 93.0 & 244.4 & 375 & 267 & 47.1 & 117.7 & 167.5 & 471 & 295 \\
\hline Bellis & 41.8 & 102.7 & 288.3 & 418 & 310 & 51.2 & 128.0 & 190.9 & 512 & 336 \\
\hline Punch & 44.0 & 110.0 & 307.4 & 440 & 332 & 54.5 & 136.3 & 209.7 & 545 & 369 \\
\hline Bayleton & 33.1 & 82.7 & 286.3 & 331 & 223 & 47.1 & 111.7 & 153.8 & 471 & 295 \\
\hline Kema-Z & 30.6 & 76.7 & 183.8 & 306 & 198 & 42.1 & 105.3 & 139.3 & 421 & 245 \\
\hline $\mathrm{AQ} 10$ & 27.2 & 69.3 & 156.6 & 272 & 164 & 38.7 & 96.7 & 119.7 & 387 & 211 \\
\hline Control & 10.8 & 27.0 & & 108 & & 17.6 & 44.0 & & 176 & \\
\hline L.S.D 0.05 & & & & & $\begin{array}{l}\text { ungicide } \\
\text { Seasons }\end{array}$ & $\begin{array}{l}\text { ): } \\
\text { ): } \\
\text { S: }\end{array}$ & & & & \\
\hline
\end{tabular}

$Y^{*}=$ Yield average number of fruits/ tree

$\mathrm{P}=$ Price of yield, Egyptian pound

$I^{*}=\%$ Increases of average number of fruits/ tree.

Profit / Egyptian pound

Price of $1 \mathrm{Kg} \mathrm{cv}$. Alphonso 2011/2012 = 10 Egyptian pound

$\mathrm{YK}^{*}=$ Yield by Average weight $\mathrm{Kg} /$ tree.

Table 8. Effect of five fungicides and one biocide on fruit yields in Fagri Kelan mango cultivars in Noubareya districts, 2011 and 2012 seasons.

\begin{tabular}{|c|c|c|c|c|c|c|c|c|c|c|}
\hline \multirow{2}{*}{ Fungicides } & \multicolumn{5}{|c|}{ 2011season } & \multicolumn{5}{|c|}{2012 season } \\
\hline & YK* & $\mathrm{Y}^{*}$ & $I^{*}$ & $\mathrm{P}$ & Profit & YK* & $\mathrm{Y}^{*}$ & $I^{*}$ & $\mathrm{P}$ & Profit \\
\hline Collis & 23.4 & 70.3 & 90 & 210.6 & 99.9 & 26.9 & 80.7 & 79.3 & 242.1 & 108 \\
\hline Bellis & 25.2 & 75.7 & 104.5 & 226.8 & 116.1 & 28.3 & 85.0 & 88.8 & 254.7 & 120.6 \\
\hline Punch & 27.1 & 81.3 & 119.7 & 243.9 & 133.2 & 31.5 & 94.7 & 110.4 & 283.5 & 149.4 \\
\hline Bayleton & 21.7 & 65.3 & 76.5 & 195.3 & 84.6 & 25.3 & 76.0 & 68.8 & 227.7 & 93.6 \\
\hline Kema-Z & 20.3 & 61.0 & 65.6 & 182.7 & 72.0 & 24.2 & 72.7 & 61.5 & 217.8 & 83.7 \\
\hline AQ 10 & 17.6 & 53.0 & 43.2 & 158.4 & 47.7 & 20.3 & 61.0 & 35.5 & 182.7 & 48.6 \\
\hline Control & 12.3 & 37.0 & & 110.7 & & 14.9 & 45.0 & & 134.1 & \\
\hline \multirow[t]{3}{*}{ L.S.D 0.05} & \multicolumn{10}{|c|}{ Fungicides(F): } \\
\hline & \multicolumn{10}{|c|}{ Seasons (S): } \\
\hline & \multicolumn{10}{|c|}{$\mathrm{F}^{*} \mathrm{~S}:$} \\
\hline
\end{tabular}

$Y^{*}=$ Yield average number of fruits/ tree

$\mathrm{P}=$ Price of yield, Egyptian pound

$I^{*}=\%$ Increases of average number of fruits/ tree.

Profit / Egyptian pound

Price of 1Kg cv. Fagri kelan 2011/2012 = 9 Egyptian pound

$\mathrm{YK}^{*}=$ Yield by Average weight $\mathrm{Kg} /$ tree. 
Data in table (9) show that spraying five fungicides and one biocide three times against the disease increased average number of fruits/tree compared to the untreated control on cv. Langara. The highest increases were observed for Punch (169.5\%), Bellis (148.4) and Collis (133.9\%). Also, using these fungicides increased the profits 346.4, 304 and 274.4 Egyptian pounds respectively compared with the control during 2011 season, whereas the least was observed with AQ10 83.2\% and the profit was 170.4 Egyptian pounds, positive increases in both criteria were also recorded in the second season tested (2012) for the same treatments somewhat similar to those of the first season (2011).

Table 9. Effect of five fungicides and one biocide on fruit yields in Langara Mango cultivars in Noubareya districts, 2011 and 2012 seasons.

\begin{tabular}{|c|c|c|c|c|c|c|c|c|c|c|}
\hline \multirow{2}{*}{ Fungicides } & \multicolumn{5}{|c|}{ 2011season } & \multicolumn{5}{|c|}{2012 season } \\
\hline & $\mathrm{YK}^{*}$ & $\mathrm{Y}^{*}$ & $\mathrm{I}^{*}$ & $\mathrm{P}$ & Profit & $\mathrm{YK}^{*}$ & $\mathrm{Y}^{*}$ & $\mathrm{I}^{*}$ & $\mathrm{P}$ & Profit \\
\hline Collis & 59.8 & 107.67 & 133.9 & 478.4 & 274.4 & 76.0 & 137.0 & 110.8 & 608 & 319.2 \\
\hline Bellis & 63.5 & 114.33 & 148.4 & 508 & 304 & 80.0 & 144.3 & 122 & 640 & 351.2 \\
\hline Punch & 68.8 & 124.00 & 169.5 & 550.4 & 346.4 & 84.9 & 153.0 & 153.3 & 679.2 & 390.4 \\
\hline Bayleton & 54.9 & 99.00 & 115.2 & 439.2 & 235.2 & 69.8 & 125.7 & 93.3 & 558.4 & 269.6 \\
\hline Kema-Z & 50.5 & 91.00 & 97.8 & 404 & 200 & 65.5 & 118.0 & 81.5 & 524 & 235.2 \\
\hline $\mathrm{AQ} 10$ & 46.8 & 84.33 & 83.2 & 374.4 & 170.4 & 59.6 & 107.3 & 65.1 & 476.8 & 188 \\
\hline Control & 25.5 & 46.00 & & 204 & & 36.1 & 65.0 & & 288.8 & \\
\hline \multirow[t]{3}{*}{ L.S.D 0.05} & \multicolumn{10}{|c|}{ Fungicides(F): $\quad 4.98$} \\
\hline & \multicolumn{10}{|c|}{ Seasons (S): } \\
\hline & \multicolumn{10}{|c|}{$\mathrm{F}^{*} \mathrm{~S}:$} \\
\hline
\end{tabular}

$\mathrm{I}^{*}=\%$ Increases of average number of fruits/ tree.

$\mathrm{P}=$ Price of yield, Egyptian pound

Profit / Egyptian pound

Price of $1 \mathrm{Kg} \mathrm{cv}$. Langara 2011/2012 = 8 Egyptian pound

$\mathrm{YK}^{*}=$ Yield by Average weight $\mathrm{Kg} / \mathrm{tree}$.

Data in Table $(\backslash 10)$ show that on cultivar Zebda, the highest percentages of increases the average number of fruits/tree observed when used Punch (111.6\%), Bellis (95.3\%) and Collis (79.7)\% .Moreover ,these fungicides increased the profits (219), (187) and (156) Egyptian pounds respectively compared with the control during 2011season. Whereas, the least percentage of increment in average number of fruits/ tree $(52.7 \%)$ was observed when AQ10 was used and the profit was 104 Egyptian 
pounds during 2011 season. somewhat similar results were obtained with the mentioned treatments in the second season (2012) on both criteria tested.

Table 10. Effect of five fungicides and one biocide on fruit yields in Zebda Mango cultivars in Noubareya districts, 2011 and 2012 seasons.

\begin{tabular}{|c|c|c|c|c|c|c|c|c|c|c|}
\hline \multirow{2}{*}{ Fungicides } & \multicolumn{5}{|c|}{ 2011season } & \multicolumn{5}{|c|}{2012 season } \\
\hline & $\mathrm{YK}^{*}$ & $\mathrm{Y}^{*}$ & $\mathrm{I}^{*}$ & $P$ & Profit & YK* & $\mathrm{Y}^{*}$ & $\mathrm{I}^{*}$ & $\mathrm{P}$ & Profit \\
\hline Collis & 29.7 & 77.3 & 79.7 & 267.3 & 118.8 & 41.9 & 109.3 & 88.4 & 377.1 & 176.4 \\
\hline Bellis & 32.3 & 84.0 & 95.3 & 290.7 & 142.2 & 43.1 & 112.3 & 93.6 & 387.9 & 187.2 \\
\hline Punch & 34.9 & 91.0 & 111.6 & 314.1 & 165.6 & 46.5 & 121.0 & 108.6 & 418.5 & 217.8 \\
\hline Bayleton & 28.5 & 74.3 & 72.7 & 253.8 & 105.3 & 37.6 & 98.0 & 68.9 & 338.4 & 137.7 \\
\hline Kema-Z & 26.9 & 70.0 & 62.7 & 242.1 & 93.6 & 35.6 & 92.7 & 59.8 & 320.4 & 119.7 \\
\hline AQ 10 & 25.2 & 65.7 & 52.7 & 226.8 & 78.3 & 31.1 & 81.0 & 39.6 & 279.9 & 79.2 \\
\hline Control & 16.5 & 43.0 & & 148.5 & & 22.3 & 58.0 & & 200.7 & \\
\hline \multirow[t]{3}{*}{ L.S.D 0.05} & \multicolumn{10}{|c|}{ Fungicides(F): } \\
\hline & \multicolumn{6}{|c|}{ Seasons (S): } & \multicolumn{4}{|c|}{2.90} \\
\hline & \multicolumn{6}{|c|}{$F^{*} S:$} & .66 & & & \\
\hline
\end{tabular}

$\mathrm{Y}^{*}=$ Yield average number of fruits/ tree.

$I^{*}=\%$ Increases of average number of fruits/ tree.

$\mathrm{P}=$ Price of yield, Egyptian pound

Profit / Egyptian pound

Price of 1Kg cv. Zebda 2011/2012 = 9 Egyptian pound

$\mathrm{YK}^{*}=$ Yield by Average weight $\mathrm{Kg} /$ tree.

\section{DISCUSSION}

Powdery mildew caused by Oidium mangiferae is one of the most serious Mango diseases, Disease survey was carried out during 2011and 2012 seasons, in the main Mango production areas in Ismailía, Sharkeya, Noubareya, Giza and Behera largest areas, however, are being reported in Ismailía, Behera and Noubareya (Anonymous, 2011). Data revealed that the severity of the disease varied from one location to another, and from season to season as well as varieties. These variable reactions may be due to various factors as environmental conditions and density of the pathogen inocula (Jayalakshmi, 2010). Data in the present study suggested that applying some fungicides and the biocide tested reduced the severity of the disease which was accompanied by less damage to chloroplasts and chlorophyll content. The fungicide Punch was more effective in this result, allowing better photosynthesis rate, photophosphorylation and CO2 assimilation (Shukanov et al., 1980, Xu Bing Liang et al., 2005 and Dinesh, 2009). 
Also, data in the present study revealed that the fungicides in concern reduced the disease significantly if spraying is applied before flowering, during flowering and after fruit set. Punch, however, gave the highest efficiency in reducing disease severity in the field under natural infection on Alphonso, Fagri Kelan, Langara and Zebda cultivars in two seasons (2011 and 2012). Likewise, the other systemic fungicides Bellis, Collis, Bayleton, and Kema-Z gave a good control in reducing the disease, As for the mode of action on the pathogen, the triazole fungicides Punch and Bayleton played a role in sterol production needed for membrane structure and function by inhibiting C14 demethylase. (Brent, 1995 and Bretthauer, 2005) Also, Kema-Z and Punch are known to disrupt "Beta-tubulin assembly during cell division." Fungicides in this group disrupt mitosis by binding to the tubulin subunits. Moreover, the fungicides. Colis and Billis belonging to carboximides group which are known to inhibit the function of a molecule within mitochondria, termed complex II, necessary to secure energy (via FADH2). During respiration, negatively charged electrons are moved across mitochondrial membranes, dragging with them protons which also accumulate behind the membrane. The protons filter back through the membrane, in an effort to reestablish equilibrium, and turn cellular turbines which generate the energy needed to sustain life. As the function of complex II molecules is inhibited, the cell's ability to transport electrons across the mitochondrial membrane is inhibited as well, also inhibiting proton movement. Our results agree with the findings of Brent (1995), Bretthauer (2005), Chavan et al., (2009) and Sharma et al., (2012).

Ampelomyces quisqualis in $\mathrm{AQ} 10$ as biocontrol agent against powdery mildews disease gave a moderate efficacy to reduce disease severity, Ampelomyces quisqualis Ces. is a fungal hyperparasites on Erysiphaceaae and other fungi. $A$. quisqualis is a potential biological control agent for powdery mildew diseases on vegetable crops, apple, Grape, and mango (Kiss et al., 2004 and Romero et al., 2007). Present results revealed that the mango yield increased when fungicides or biocide where applied as spraying treatment compared to the untreated control on all cultivars tested. Percentages of increase in average number of fruits/ tree ranged from $307.4 \%$ to $35.5 \%$. Increasing the number of fruits produced with fungicides and biocides spraying treatments may due to retention flowering trees health, the large percentage of them turn to fruits as well the fruit does fall in the early stages. These results are not agreeable with the findings of Galli J et al., (2008) which mentioned that the presence or absence of powdery mildew symptoms had no effect on fruit yield but they agree with those found by Nofal et al., (2006) and Haggag, (2010). Reducing disease incidence and severity would result in maintaining healthy 
chloroplasts. Consequently, photosynthesis tends to be normal. Such conditions would result in sufficient photosynthates that reflect as an increase in yield.

\section{REFERENCES}

1. Anonymous. 2011. Annual Report of Agric. Statistical Dept. Egyptian Min .of Agric., A.R.E. (In Arabic).

2. Brent, Keith, J. 1995. Fungicide Resistance in Crop Pathogens: How can it be managed. Fungicide Resistance Action Committee (April)

(http://www.frac.info/publications.html). Accessed October, 2004.

3. Bretthauer, Scott. 2005. Report on Plant Disease: Characteristics of Fungicides Used in Field Crops. University of Illinois. (September). (http://www.ag.uiuc.edu/ vista/abstracts/a1002.html). Accessed March, 2006.

4. Chavan, R. A.,V.D. Deshmukh, S.V. Tawade, and J.D. Deshmukh. 2009. Efficacy of fungicides for managing powdery mildew of Mango International Journal of Plant Protection, 2 (1): 71-72

5. Dinesh, B. M. 2009. Studies on powdery mildew of sunflower caused by Erysiphe cichoracearum DC. M.Sc. Thesis University of Agricultural Sciences, Dharwad, India.

6. Galli, J. A., Silvera, L. C. P., Michelotto, M. D. and Martinis, A.L. M. 2008. Powdery mildew (Oidium mangiferae Bert.) infection on Mango varieties. Biosci. J., Uberlândia, 24(2): 43-46.

7. Haggag, M. 2010. Mango diseases in Egypt. Agric. Biol. J., 1(3): 285-289.

8. Jayalakshmi, K, 2010. Studies on anthracnose of Pomegranate caused by Colletotrichum gloeosporioides (Penz.). M.Sc.Thesis, Fac. Agric., Univ. Agric, Sci., India.

9. Kiss, L., J.C. Russell, O. Szentivanyi, Xu, X., P. Jeffries. 2004. Biology and biocontrol potential of Ampelomyces mycoparasites, natural antagonists of powdery mildew fungus. Biocontrol Science and Technology 14, 635-51.

10. Monje, O. A. and B. Bugbee. 1992. Inherent limitations of nondestructive chlorophyll meters. A comparison of two types of meters. Hort. Sci., 27: 69-71.

11. Nofal, M.A. and Wafaa, M. Haggag . 2006. Integrated pest management for the control of powdery mildew on mango trees in Egypt. Crop Protection 25: 480486.

12. Romero, D. A. de Vicente, H. Zeriouh, F. M. Cazorla, D. Fernández-Ortuñob, J. A. Torés and A. Pérez-García. 2007. Evaluation of biological control agents for 
managing cucurbit powdery mildew on greenhouse-grown melon. Plant Pathology 56, 976-986

13. Sharma H., G.B. Kalaria, P.D. Ghoghari and V. Khandelwal. 2012. Bioefficacy of different chemical fungicides for the management of mango powdery mildew in south Gujarat. J Mycol. PI. Pathol., 42(4): 494-496.

14. Shukanov, A. S., N. A. Lemeza and A. P. Gulevich. 1980. Changes in pigment content and photochemical activity of chloroplasts in flax plants infected by powdery mildew. Mikologiya I Fitopatologiya, 14(2): 117-122.

15. Thind, S.K, J.S. Josan and V.K. Vij. 2005. Fungicidal management of powdery mildew of Mango in Punjab, India. Proc. Internat. Conf. on Mango and Date palm : Cultural and export. $20^{\text {th }}$ to $23^{\text {th }}$ June, University of Agricultural, Faisalabad, Pakistan.

16. Xu Bing Liang, Li Min Quan, Yu Ji Hua and Xing Hui Qin. 2005. Correlation between chlorophyll content and resistance to powdery mildew (E. polygoni) in lucerne. Pratacultural Sci., 22(4): 72-77. 


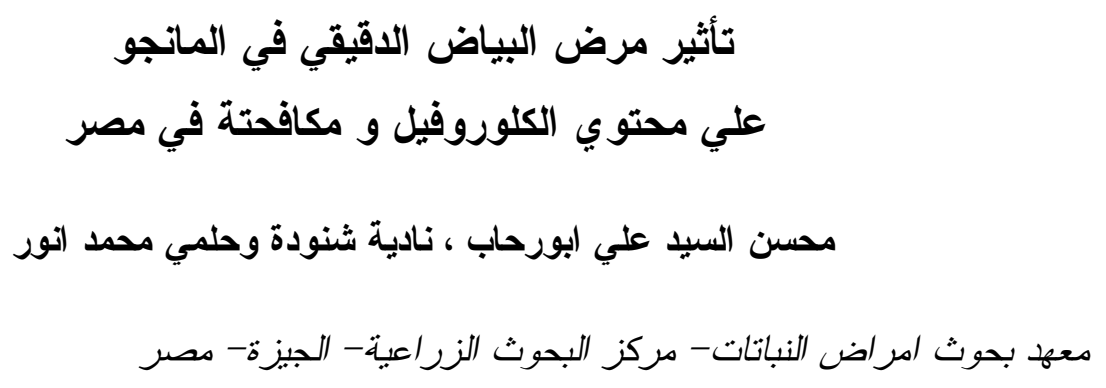

يعتبر مرض البياض الدقيقي علي أنثجار المانجو في مصر والمتسبب عن الفطر أوديم مانجيفير ا من الامر اض الهامة اقتصاديا والتي تؤدي الي خسائر كبيرة في المحصول علي المستوي القومي ـ لذلك تم اجر اء حصر لانتشار المرض وشدتة في خمس محافظات هي الجيزة و البحيرة

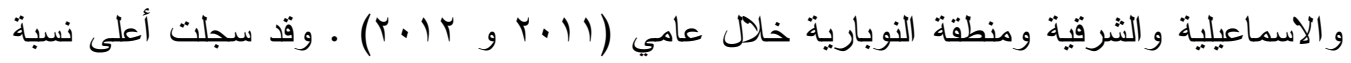

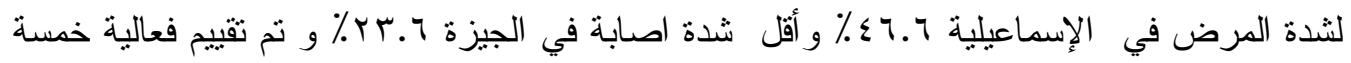
مبيدات كيماوية وهي البيليز ، الكوليز ، البانش ، كيمازد و البايليتون و المبيد الحيوي 10 AQ ضده ولده

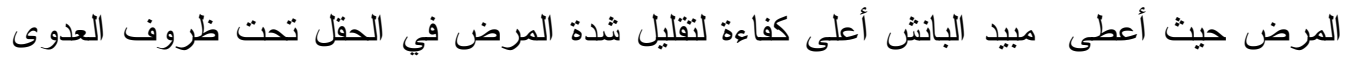

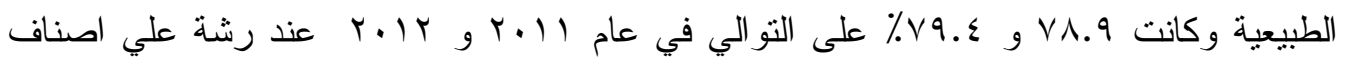

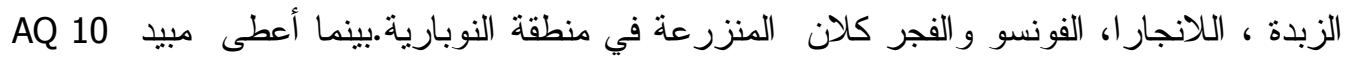

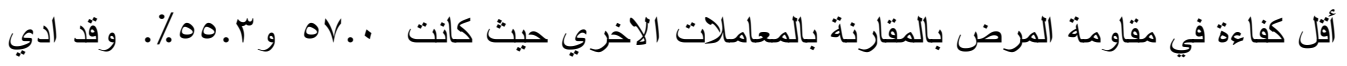

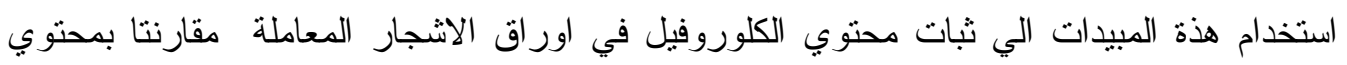

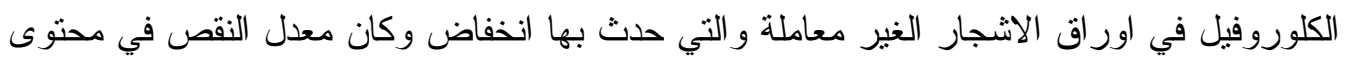

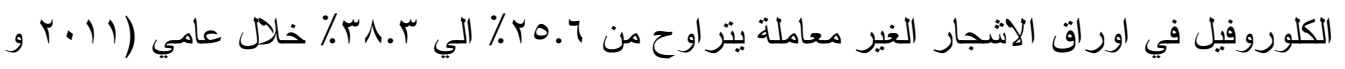

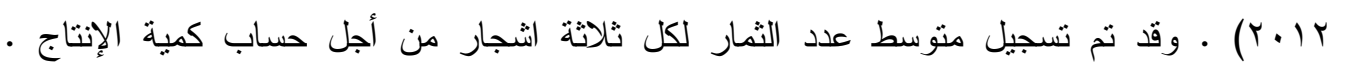

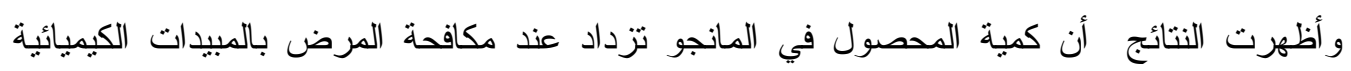

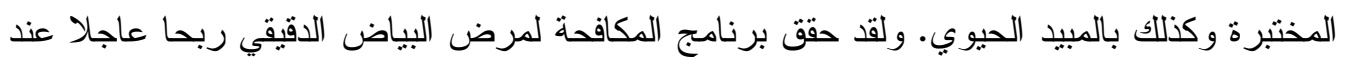

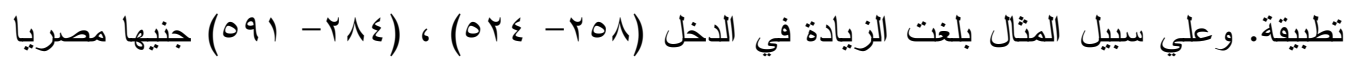
في السنة الاولي و الثانية للتجريب علي التو الي في حالة الصنف لانجار ا. 